\title{
Ssciendo
}

Ethics \& Bioethics (in Central Europe), 2020, 10 (1-2), 1-9

DOI:10.2478/ebce-2020-0009

\section{Prolonged life and good death in Antiquity ${ }^{1}$}

\author{
Svetlana Martynova² \& Denis Bugaev ${ }^{3}$
}

\begin{abstract}
This paper studies the connections between the notions of prolonging life and a good death in Antiquity. It is demonstrated that while prolonged life generally meant forestalling the human constitution's death, ancient philosophers also pointed to the limitations of prolongation. The paper shows how philosophers welcomed prolonged life when it was shown to foster movement toward the good, such as self-realization and social usefulness. Yet, they rejected prolongation when it led to the perpetuation of evil, such as social uselessness and suffering. We ask whether a contemporary good death is a mercy killing or an improvement of prolonged life, as the ultimate end of "goods practicable for man".
\end{abstract}

Keywords: euthanasia, good death, prolonged life, the end, physician, medicine, social usefulness, self-realization, Hippocrates, Plato, Aristotle

\section{Introduction}

What is a prolonged life? It is a life supported by a combination of lifestyle, medication, and technology. A person chooses how to take care of, or indeed neglect, one's own body. We can develop a healthy lifestyle to prevent the body from losing its functions. We can strain every sinew and stimulate every nerve via medication. We can amputate limbs in order to save the body as a whole and fit a prosthesis as a replacement. Today, it is possible to extend human life for a substantial amount of time through gene modifications, immunization, organ transplantation, and so on. It is an issue of gerontology. Aubrey de Grey suggests that contemporary humans aged 50-60 could live for 1,000 more years. This goal is said to be reachable by incrementally renovating the human body every 10-20 years in parallel with the advent of new technologies (de Grey, 2017).

But the prolongation of life raises some thorny questions for and about humanity. Research in bioethics addresses the issue of supporting human life by all means. For instance, Gluchman deems it immoral to prolong human life simply at the level of biological survival (Gluchman, 2005 , p. 617). Indeed, we agree that to prolong life without appealing to some notion of human dignity is not good for human beings. That is, without a conception of human self-realization and social activity, a prolonged life is seldom worth living.

It is precisely such a situation that may be the reason behind the recent growth in discussions about euthanasia. The loss of social activity and self-realization leads to problems in clearly delineating what constitutes death. As such, we think it is worth asking: Should we accept the absence of social activity and self-realization? Do we have a moral right to return to the natural limitations of life, to the death of a person? Why is it that many attempts to prolong life are being rejected nowadays, and is this leading to an increase in instances of euthanasia (mercy killings)?

In the contemporary context, euthanasia refers to a mercy killing. Euthanasia entails the decision on the part of a patient and a physician to bring an end (either passively or actively) to human suffering and to have a good death. In earlier times, the term euthanasia

\footnotetext{
${ }^{1}$ The paper was presented at the international conference End of Life and Euthanasia - Intersection of Issues and Questions held in Prague (Czech Republic) on 4-5 November 2019.

${ }^{2}$ Herzen State Pedagogical University of Russia, Department of Philosophical Anthropology and History of Philosophy; svetlanus.martinova@yandex.ru

${ }^{3}$ University of Warsaw, Faculty of History; denisbugaev@yahoo.com
} 
(from Greek: $\varepsilon \dot{v} \theta \alpha v \alpha \sigma i ́ \alpha)$ also meant a good death, yet this was not linked to the idea of providing ongoing medical support to the patient until his death. As van Hoof notes, in its varied historical and linguistic uses, "euthanasia and its derivatives conveyed the idea of a comfortable, happy and noble end" (van Hoof, 2004, p. 976). Despite its mutations over time, euthanasia has long been discussed in relation to the connection between a prolonged life and a good death.

In Antiquity, Hippocrates and Plato partly rejected the necessity of life's prolongation in medical practice. Prolonged life was a delaying of the body's death. According to them, a good death occurs without the prolonging of life. Aristotle offered a different perspective in this regard. For him, life's prolongation was possible after the time of one's natural death. For euthanasia (a good death), nobody needs to refuse life's prolongation. The purpose of this article is to research the connection between the rejection/acceptance of prolonged life and a good death (euthanasia). Our first step toward this end is to explain the possibility for people today to decide to undergo euthanasia (a good death) by themselves in the face of a potentially prolonged life.

To research the rejection of life's prolongation in order to have a good death, we refer to Hippocrates' and Plato's texts. We explore Hippocrates' conception of a good death as a result of a physician's acceptance of the impossibility of prolonging life. We then refer to Plato's idea of a good death and his critique of prolonged life. To study the acceptance of a prolonged life without contradicting the notion of a good death, we refer to Aristotle's thoughts, which can help not only to explain euthanasia as an instrument to restrict the prolongation of life today, but also to highlight the necessity for individuals to have the opportunity for self-realization and social activity.

\section{Hippocrates' conception of the tasks of medicine, physicians' prognoses, and a good death}

In the existing literature concerning the issue of euthanasia in ancient texts, Kuře examines Hippocrates' view on the topic. According to Kuře, Hippocrates' relation to the notion of a good death is based on the sanctity of life. Life is given by the gods and the end of life is not within man's command. As a result, a good death is one without any medical intervention (Kuree, 2011, p. 8). From this, one might think that refusing to influence the patient also involves deciding to prevent any prolongation of life. Yet, does such a view mean that a physician may not prolong life in other cases? Does a physician stop prolonging life in order to secure a good death?

Some researchers suppose that prolonged life was not a goal of Hippocrates' medical practice (Shneiderman, 2000, p. 6). In our view, prolongation was not particularly evident in Antiquity because Hippocrates focused on the cosmetic tasks of medicine and the physician's skill in returning functionality to the patient (the sick returning to health). In addition, he spoke of the need to preserve one's health, promoting bodily strength. To obtain these results, he preferred to discuss gymnastics, ptisans, and so on (Hippocrates, 1959d, p. 71).

We think that it is necessary to explore prolongation and its limitations (when it made no sense when confronted with death) in Antiquity. The decision to prolong life was an essential part of physicians' practice through surgery. The physician cared for sick people with wounds, brain injuries, and so on. He had to use special instruments to solve problems and, as a result, exerted a major influence on the patient's longevity of life. For example, Hippocrates discusses removing dry bones from a skull (Hippocrates, 1959b, pp. 39-41), gangrene, a special method for severe fractures (Hippocrates, 1959a, p. 127), wooden tools for severe fractures and dislocations of legs (Hippocrates, 1959a, pp. 129-131, 135-137, 145, 165-169), dead parts of flesh and bones (Hippocrates, 1959a, pp. 157-163), mechanical instruments (Hippocrates, 1959a, pp. 169-175), and the severing and extraction of dead bones (Hippocrates, 1959a, p. 179). 
The decision to stop the prolongation of life was undertaken by a physician in some cases. To understand when this was possible, we need to appeal to the physician's duty to define the state of the body and to prognose a person's death. According to Hippocrates, a physician defines the state of the body in order to ascertain whether or not it will live. Hippocrates writes that the physician has to observe diseases and "how much they exceed the strength of men's bodies [...] you will be blameless if you learn and declare beforehand those who will die and those who will get better" (Hippocrates, 1959c, pp. 7-9).

The loss of the powers of the constitution affects the physician's decision about treatment and prolongation. Hippocrates says that a physician should leave bad cases of fractures and not intervene in them (Hippocrates, 1959a, p. 181). Moreover, if a man suffers from tetanus, the physician should cease performing mechanical actions in vain (Hippocrates, 1959a, p. 175). All these cases speak to the loss of the powers of the constitution and impending death. As such, in these cases the physician decides to do nothing with the patient's constitution; he does not try to prolong life by way of intervening with the body. Indeed, it was usual practice for a physician to not partake in the process of dying (van Hoof, 2004).

The rejection of a prolonged life was connected not only with the loss of the power of the patient's constitution, but also with the latter's age. Hippocrates traces linkages between the age of patients and the influence of diseases on their well-being and death. For example, he discusses types of empyema for the dying old or young (Hippocrates, 1959c, pp. 39-41). He notes that pains in the bladder are fatal for seven- to 15-year-olds (Hippocrates, 1959c, p. 41). He observes that in deaths from acute pain of the ear, younger patients die in less than seven days, while older patients die later (Hippocrates, 1959c, pp. 45-47). Hippocrates notes that depositions in joints are common in persons under the age of 30, but are less common in those over the age of one (Hippocrates, 1959c, pp. 49-51). In instances of vomiting in people, he notes that while convulsions are harder for children under the age of seven, those over this age experience fewer convulsions (Hippocrates, 1959c, p. 53). Some ages were used as a reason to make a statement about the coming of death. Since a physician did not intervene in the dying process, they were advised to ignore the patient if he/she was of an age at which it was not appropriate or feasible to resist the disease. The option to prolong life was not possible for someone who could not be healthy due to their age.

Thus, we can conclude that Hippocrates' conception establishes a different view on the prolongation of life for two categories of people. A physician would opt to delay the onset of death if the patient was able to become healthy again. Prolongation was forbidden for dying people and for those who could not return to health on account of their age. According to Hippocrates, it was impossible to change anything in the divine order (the diseases could not be removed). Thus, a physician had to accept this order, recognize the patient's impending death, and leave him to make his death good.

\section{Plato's idea of a good death and his critique of prolonged life}

Kuře points to the difference between Plato's and Hippocrates' explanations of the good death. While Plato continues to think about a good death as being in the gift of the gods, he nevertheless makes some exceptions. It is better to die than to live in cases of the need to die (Socrates' death), shame of extreme suffering, poverty, or disaster, incorrigible maleficence, irredeemable crime, terminal illnesses, and so on (Kuře, 2011, p. 9). This view differs from that of Hippocrates who maintained the sanctity of life and did not suppose that it was possible to interrupt life.

Plato's view of the prolongation of life was quite disapproving. In light of a good death, the prolonging of life makes no sense; indeed, it may even stand in opposition to it. In Phaedo, Plato recounts Socrates' good death and the possibility of him prolonging life before death. Socrates is against this because it makes no sense. Moreover, the embodiment of the soul in any 
body is a kind of imprisonment. So, according to Plato, prolongation is detrimental to death. It restricts the soul's chances of being free (Plato, 1966, 84a-84b). As Georgios Anagnastopoulos underlines: "prolonging life is prolonging evil" (Anagnastopoulos, 2001, p. 263).

Plato comments on the foolishness of prolonging life for the sake of a good death in Timaeus. Plato's thinking here is in accordance with Hippocrates' idea about the inevitability of death as a cause to stop the prolongation of life. Plato writes: "For not the whole race only, but each individual - barring inevitable accidents - comes into the world having a fixed span, and the triangles in us are originally framed with power to last for a certain time, beyond which no man can prolong his life" (Plato, 1969b, 86b-90d). A man has to accept the limits of his life and does not try to prolong what is coming to an inevitable end. Human life is in the possession of the gods, and as such prolongation is senseless.

There is a contradiction between a good death and prolonged life in Plato's Republic. To tease out this contradiction, we need to consider Plato's various positions both for and against prolonged life in this text.

Prolonged life serves to forestall the death of the human constitution. Plato welcomes prolonged life in some cases. Like Hippocrates, Plato thinks that it is good to undergo treatment and prolong life in the case of trauma or seasonal diseases. Plato writes about treatment and the prolongation of life by way of medicine: "that for those who were by nature and course of life sound of body but had some localized disease, that for such, I say, and for this habit he revealed the art of medicine, and, driving out their disease by drugs and surgery, prescribed for them their customary regimen" (Plato, 1969a, 407d).

Plato speaks against prolonged life in the next fragments. In Book 1 of the Republic, Plato discusses unnecessary prolongation in relation to Gerodic who, having an incurable malady, stretched out his death and did nothing more. ${ }^{4}$ Plato appeals to Aesculapius, and notes that "for all well-governed peoples there is a work assigned to each man in the city which he must perform, and no one has leisure to be sick and doctor himself all his days" (Plato, 1969a, 406c). According to Plato, Gerodic's prolongation was bad because it supported a man who was not able to be healthy and useful to society. Such a prolonged life leads to weakness, suffering, fear, and the supporting of disease and social exclusion. Instead of prolonging his life, it would have been better for Gerodic to have died.

There is one more fragment in which Plato speaks about when it is right to refuse to prolong life. Plato appealed again to Aesculapius, writing: "when bodies were diseased inwardly and throughout, he did not attempt by diet and by gradual evacuations and infusions to prolong a wretched existence for the man and have him beget in all likelihood similar wretched offspring. But if a man was incapable of living in the established round and order of life, he did not think it worthwhile to treat him, since such a fellow is of no use either to himself or to the state" (Plato, 1969a, 407d). In this fragment, life's prolongation is also interpreted as bad because it supports a man who was unable to be free from the illness and to be of use to society. Plato adds one more component to this thought: utility for himself. This refers to man's inability to move toward knowledge and the good. This fragment, like the previous one, shows that it is better to move toward death than to support an ill state.

Here we ought to observe that Plato's view in the Republic on the inability to be healthy differs from the concept of coming death. In the cited fragments, Plato mentions incurable and longstanding diseases inside the body. According to him, both types of disease are similar insofar as it is impossible to be cured of a longstanding disease. Moreover, Plato is not interested in diseases per se, but rather in how they are evaluated and accepted by an individual (that is,

\footnotetext{
${ }^{4}$ As Plato notes: "for living in perpetual observance of his malady, which was incurable, he was not able to effect a cure, but lived through his days unfit for the business of life, suffering the tortures of the damned if he departed a whit from his fixed regimen, and struggling against death by reason of his science he won the prize of a doting old age" (Plato, 1969a, 406b).
} 
recognizing the reality that the disease can be cured). The inability to be healthy is a bodily state (incurable illness) and/or man's agreement with his bad state and his caring about this state (a man is not able to think about or do anything other than delay the onset of death). Plato points to this as a reason to stop life's prolongation. To prolong this state is not just senseless; it is also bad because of the spreading of diseases, fear, suffering, and man's social uselessness.

According to Plato's thinking as presented in the Republic, prolonged life in some cases establishes what a good death denies - weakness, diseases, suffering, poverty, and uselessness for society. This contradiction is no accident. There are two options open to man when he feels himself bad and cannot take part in social life: the prolonged life and the good death. A man may agree to the prolongation of life that supports illness and fosters uselessness for himself and for society as a whole. Or he may choose a good death and avoid these bad things. Plato supposes that when faced with such a choice, man must prefer a good death. Man should reject prolongation for a good death and prevent the spread of evil.

We can conclude, then, that Plato criticizes the notion of prolongation, since it makes no sense in light of the fact that a human life depends on the power of the gods. Prolongation leads to evil as it stops the soul from being free from the body (Socrates' case). Prolongation may also lead to evil as it supports the spreading of diseases, suffering, and uselessness. Plato's idea of the good death as surrendering to the power of gods, alongside the need to die and avoid suffering, chronic diseases, poverty, disaster, maleficence, and crime, conflicts with the idea of prolonged life. For Plato, we should reject prolonged life so that we may reach a good death.

\section{Accepting prolonged life without contradicting the notion of a good death: Aristotle's conception}

Aristotle's view on death is different from that of Plato. Aristotle thinks that in all cases, death stops the spreading of goodness. Death is the worst thing in the world because it is the end and it makes it impossible for the dead to have a relationship with good or evil (Aristotle, 1934, 1115a).

To understand how man can best approach death, and especially seek to secure a good death, we may appeal to the conception of the end, since death is also an end (like health, being well off, and so on). Aristotle discusses the notion of the end in Eudemian Ethics. He supposes that while nobody is able to choose their end, one is able to choose the means to reach it. For example, a man may take a walk in order to be healthy or have a business so as to be well off (Aristotle, 1981, 1226a).

In this vein, we may suppose that there are different means to reach the end of death (active duty, suicide, "natural" causes, life's prolongation). And what about a "good death" as the end? Do some of the means lead to a "good death"? Aristotle supposes that it is possible to reach a good death by special means. As Kuře emphasizes, in Aristotle's works, a good death occurs in situations when a courageous man is able to meet death resolutely and without fear (Kurre, 2011, p. 9). However, it is not easy to be such a man. As Matthews notes, Aristotle separates the spontaneous acts of man from his habit of being courageous. It is not enough for a courageous man to act spontaneously. Rather, he must foster courage as a constant virtue; it is the result of man's work with his own desires, fears, and so on. Matthews concludes: "To ask what motivates an already brave soldier to perform an act that leads to a noble death should not, therefore, be to ask simply what goes through the soldier's mind at the moment he made the decision to perform the action Aristotle would honor him for" (Matthews, 2012, pp. 197-198).

We propose one more means through which to have a good death with reference to Aristotle's notion of the "good end". The good death or good end occurs when a man is able to fulfill his deals and obligations, and to complete what he has started during his lifetime. Man 
bears these deals and obligations according to his physical and mental health. ${ }^{5}$ Aristotle writes in Eudemian Ethics: "There is also evidence of the opinion that a person is not happy for one day only, and that a child is not happy, nor any period of life (hence also Solon's advice holds good, not to call a man happy while he is alive, but only when he has reached the end), for nothing incomplete is happy, since it is not a whole" (Aristotle, 1981, 2019b). Aristotle proves that a happy man should reach the end and the whole by completing everything he has started. According to this logic, death could be good if man completes all his deals and obligations by the time of his death. In particular, death is good if man can attain the absolute good. As Aristotle puts it, "the Absolute Good would be this - the End of the goods practicable for man" (Aristotle, 1981, 1218b).

What does Aristotle think about the notion of prolonged life? Does it contradict his opinion about the good death? Stambler focuses on some of the different ways to prolong human life: a gentle and friendly environment, economical heat expenditure, a diet rich in "heat and moisture". However, Stambler is certain that we cannot speak in favor of radical prolongation by way of Aristotle's conception. Immortality is not Aristotle's task (Stambler, 2017, p. 217). We agree that there is no defense of radical life extension to be found in Aristotle's philosophy. We would add to this an explanation of the purposes of prolonged life, as well as its specificity and its correlation with a good death.

We think that the idea of prolonged life lies in Aristotle's conception of different stages of life. ${ }^{6}$ Aristotle writes that "youth is the period of the growth of the primary organ of refrigeration, old age of its decay, while the intervening time is the prime of life" (Aristotle, 1995b (1), 479a29-31). Furthermore, Aristotle distinguishes between violent death or dissolution, natural death, and death in old age. The cause of violent death is the exhaustion of vital heat; the cause of natural death is the exhaustion of heat over time; the cause of death in old age is an inability of the body to produce proper refrigeration.

Why are these stages important for our study of life's prolongation? We can see that death in old age is not the same as a natural death, because they have different causes (in one case it is the loss of heat, and in the other it is the loss of refrigeration), and death in old age comes after a natural one. So, there is a passage from a natural death to death in old age. This passage is determined by a saving and increasing of heat in the body because death in old age occurs without the loss of the heat.

In some works, Aristotle points to heat as a condition of longevity (Aristotle, 1995a). So, supporting and increasing the level of heat in a body is a form of prolonging life. As Aristotle distinguishes between natural death and death in old age, prolonged life is a supporting and increasing of heat in the body until a man is unable to produce adequate refrigeration in old age. This means that prolongation is an instrument for a patient to reach old age beyond the bounds of his possible natural death. Reaching old age is a task of prolongation.

What about the specificity of prolonged life in Aristotle's conception? Aristotle develops Hippocrates' and Plato's view on prolongation and underlines the importance of life's prolongation during life itself. The definition of prolonged life as being out of natural death can lead to the illusion that the prolongation of life is possible only after a loss of heat. Yet, this is wrong. The loss of heat is not obvious to the young, but it is a problem in old age. So, the heat should be preserved and increased in the human body during one's life in order to protect

\footnotetext{
${ }^{5}$ One could view vice as a mental illness. Müller supposes that the vicious agent lacks any real principles of action or conception of the good (Müller, 2015).

${ }^{6}$ It is not a problem that Aristotle makes this statement in relation to animals, for what he writes about animals also holds for human beings. Medicine is for every living organism. The statement that medicine is a "knowledge of what makes for health in animals and men" is misleading because a man is also an animal (Aristotle, 1995c, 141a19-20).
} 
against its loss in old age. The process of properly accumulating and protecting heat becomes a lifestyle.

We have noted that Ancient philosophers have developed different views on prolongation. If Plato and Hippocrates use it as a treatment for traumas and seasonal diseases, no prolongation is seen to be necessary for a man moving towards death and who has weakness and chronic diseases. Meanwhile, Aristotle considers the case for prolonging human life without these conditions being met. In his view, prolongation is a fight against the body's natural exhaustion.

In this way, we just need to determine the connection between a good death and prolonged life. We have set out above the differences between Ancient views on the correlation between a good death and prolonged life. In Hippocrates' and Plato's conceptions, a good death is opposed to prolongation. For them, we need not extend the bout of diseases, suffering, the soul's imprisonment, man's social uselessness, and so on. By contrast, according to Aristotle, prolonged life does not contradict the notion of a good death. The reaching of old age via life's prolongation is appropriate for man's rightful tasks: to fulfill all duties, to complete all deals, to become brave. Thus, the prolongation of life may be useful for attaining a good death.

\section{Conclusion: Euthanasia because of prolonged life today}

In our contemporary context, prolonged life is based on a patient's desire to live longer and the doctor's agreement with this. Euthanasia (mercy killing) is not just a doctor's decision. Nowadays, it is a patient's decision, too. Euthanasia is undertaken in response to a patient's acute suffering. In our view, today euthanasia may be committed and for other purposes. Social activity and self-realization are ignored in the case of life's prolongation. The use of euthanasia may revive some of the ancient limitations of prolonged life. Euthanasia may weaken the case for prolonged life and resurrect certain historical criticisms of it (as in Plato's tradition, for instance).

In this vein, might a recovery of the ancient perspectives on the limits of prolonged life help us to understand euthanasia as an attempt to resolve this issue? Martin Gluchman argues: "Death would be the manifestation of humanity in the case of escaping suffering when terrible pain is born by a terminally ill patient. On the contrary, death is the manifestation of inhumanity when killing, as a crime in its proper meaning, happens" (Gluchman, 2019, p. 87). Indeed, euthanasia as a method to replace prolonged life is not the best solution when prolonged life may be useful for good things and may be without pain and suffering (in accordance with the level of technological capabilities).

In our view, it is possible to achieve a good death not only by way of euthanasia (in the modern sense), but also via prolonged life. Ancient philosophers offer support for this position. While they did not like the idea of a radically prolonged life, the philosophers of Antiquity welcomed prolonged life when linked with movements toward the good (self-realization, social usefulness, etc.). Some of them even maintained that the idea of prolonged life need not contradict that of a good death (Aristotle). Philosophers were against the prolongation of life when it correlated with evil (suffering, uselessness, diseases, crime), in which case it was rejected in favor of securing a good death. Of course, nowadays, we have different opinions about what constitutes good and evil. But it is important to define how it is possible to have a good death in light of the possibility of prolonged life. Is it a form of euthanasia (as in a mercy killing)? Or is the prolonging of life perhaps better understood as improving the "goods practicable for a man"?

\section{Acknowledgement}

The reported study was funded by RFBR as a partial outcome of research project № 19-01100899. 


\section{References}

ANAGNASTOPOULOS, G. (2001): Euthanasia and the physician's role: Reflections on some views in the Ancient Greek tradition. In: M. G. Kuczewski \& R. Polansky (eds.): Bioethics: Ancient themes in contemporary issues. Cambridge, MA: MIT Press, pp. 251-291.

ARISTOTLE (1934): Nicomachean Ethics. In: Aristotle in 23 Volumes, vol. 19, trans. H. Rackman. Cambridge, MA: Harvard University Press.

ARISTOTLE (1981): Eudemian Ethics. In: Aristotle in 23 Volumes, vol. 20, trans. H. Rackman. Cambridge, MA: Harvard University Press.

ARISTOTLE (1995a): On length and shortness of life. In: The complete works of Aristotle in two volumes, vol. 1, trans. G. R. T. Ross. Princeton, NJ \& Chichester: Princeton University Press, pp. 740-744.

ARISTOTLE (1995b): On youth, old age, life and death, and respiration. In: The complete works of Aristotle in two volumes, vol. 1, trans. G. R. T. Ross. Princeton, NJ \& Chichester: Princeton University Press, pp. 745-763.

ARISTOTLE (1995c): Topics. In: The complete works of Aristotle in two volumes, vol. 1, trans. W. A. Pickard-Cambridge. Princeton, NJ \& Chichester: Princeton University Press, pp. 167277.

COOPER, J. M. (1989): Greek philosophers on euthanasia and suicide. In: B. A. Brody (ed.). Suicide and euthanasia: Historical and contemporary themes. Boston: Kluwer Academic, pp. 9-38.

De GREY, A. (2017): Can humans live for 1,000 years? Rejuvenation biology says Yes. In: Rejuvenation biology: How aging is changing. [online] [Retrieved December 27, 2019] Available at: https://www.youtube.com/watch?v=EGZzHfXCyXQ

GLUCHMAN, M. (2019): Different approaches to the relationship of life and death (review of articles). In: Ethics \& Bioethics (in Central Europe), 9(1-2), pp. 87-97.

GLUCHMAN, V. (2005): Miesto humánnosti v etike sociálnych dôsledkov [The place of humanity in the ethics of social consequences]. In: Filozofia, 60(8), pp. 613-623.

HIPPOCRATES (1959a): On fractures. In: Hippocrates, vol. III, trans. E. T. Withington. London: William Heinemann Ltd. \& Cambridge, MA: Harvard University Press, pp. 95-200.

HIPPOCRATES (1959b): On wounds in the head. In: Hippocrates, vol. III, trans. E. T. Withington. London: William Heinemann Ltd. \& Cambridge, MA: Harvard University Press, pp. 1-52.

HIPPOCRATES (1959c): Prognostic. In: Hippocrates, vol. II, trans. W. H. S. Jones. London: William Heinemann Ltd. \& Cambridge, MA: Harvard University Press, pp. 1-56.

HIPPOCRATES (1959d): Regimen in acute diseases. In: Hippocrates, vol. II, trans. W. H. S. Jones. London: William Heinemann Ltd. \& Cambridge, MA: Harvard University Press, pp. 57126.

KUŘE, J. (2011): Good death within its historical context and as a contemporary challenge: A philosophical clarification of the concept of "Euthanasia". In: J. Kuře (ed.): Euthanasia: The "good death" controversy in humans and animals. London: InTech, pp. 3-44.

MATTHEWS, G. B. (2012): Death in Socrates, Plato, and Aristotle. In: B. Bradley, F. Feldman and J. Johansson (eds.): The Oxford handbook of philosophy of death. Oxford: Oxford University Press, pp. 186-199.

MÜLLER, J. (2015): Aristotle on vice. In: British Journal for the History of Philosophy, 23(3), pp. $459-477$.

PLATO (1966): Phaedo. In: Plato in Twelve Volumes, vol. 1, trans. H. N. Fowler. Cambridge, MA: Harvard University Press. [online] [Retrieved December 23, 2019] Available at: http://www.perseus.tufts.edu/hopper/text.jsp?doc=Perseus:text:1999.01.0170 
PLATO (1969a): Republic. In: Plato in Twelve Volumes, vols. 5 and 6, trans. P. Shorey. Cambridge, MA: Harvard University Press. [online] [Retrieved December 23, 2019] Available at: http://www.perseus.tufts.edu/hopper/text.jsp?doc=Perseus:text:1999.01.0168

PLATO (1969b): Timaeus. In: Plato in Twelve Volumes, vol. 9, trans. W. R. M. Lamb. Cambridge, MA: Harvard University Press. [online] [Retrieved December 23, 2019] Available at: http://www.perseus.tufts.edu/hopper/text?doc=Perseus:text:1999.01.0180:text=Tim.

SHNEIDERMAN, L. (2000): Wrong medicine: Doctors, patients, and futile treatment. Baltimore: The Johns Hopkins University Press.

STAMBLER, I. (2017): Longevity promotion: Multidisciplinary perspectives. Rishon Lezion: Longevity History.

VAN HOOF, A. J. L. (2004): Ancient euthanasia: "Good death" and the doctor in the GraecoRoman world. In: Social Science \& Medicine, 58(5), pp. 975-985. 